\title{
Mindfulness and Ubuntu: Foundations for Inner Health
}

\section{Heather Greaves}

Yoga to Go Studio,106-108 Crystal Street, Petersham, NSW, Australia

\author{
Corresponding author \\ Heather Greaves, Yoga to Go Studio 106-108 Crystal Street, Petersham, \\ NSW, 2049, Australia. Tel: +61 2 9569-0870; E-mail: info@yogatogo.com
}

Submitted: 11 Mar 2019; Accepted: 23 Mar 2019; Published: 30 Mar 2019

Citation: Heather Greaves. (2019). Mindfulness and Ubuntu: Foundations for Inner Health. Med.Clin.Res, 4(4), 1-3.

\section{Introduction}

Presented here are thoughts of inner health, mindfulness, and Ubuntu. Inner health for this purpose is a state of well-being and abiding peace; and not the absence of mental health diagnosis. Mindfulness as a concept is ubiquitous, and ever increasing numbers of children, youth and adults practice this ancient tradition. Ubuntu is a cooperative way of living, anchored in the understanding of the interconnectedness of humans and nature. The African philosophy, Ubuntu, recognizes that each person has unique gifts; the person embedded in community enriches herself and community.

For over 30 years mindfulness developed mind-body synergy in a secular way in health care in the West. It subsequently made inroads in mental health care and education. Being mindful is intrinsic in ancient mind-body-spirit transformation disciplines, like yoga. The mindfulness practice spreading in the West originated within Buddhism. Today, various sectors in society explore and accept mindfulness as a mind-body practice without the language, teachers, and texts of Buddhism. Still practitioners experience an increase in spiritual qualities like serenity, gratitude, and compassion.

I propose that spirituality promotes a feeling of inner abiding peace. That a community roots the person by nurturing a sense of belonging. Furthermore, ethical communities provide spiritual growth and development of the communal self. First, I review mindfulness and its growth as a practice in the West. Then, examine research on the mental state of youth in the Western World. Next I highlight the probability that individuality and self-fulfillment have an adverse impact. Finally, I discuss definitions of spirituality and introduce Ubuntu as the human "heart".

\section{Mindfulness with and without Buddhism}

Buddhism is a contemplative practice that probes the workings of the mind. Buddhist monks have devoted their lives to this formal inquiry supported by texts. Commentaries written on the Buddhist texts include Teachings on Thought-Training, and Mind and Awareness. The body-mind-spirit relationship in Buddhism guides mindful living. Thich Nhat Hahn, Zen Master, Global Spiritual Leader, Poet, and Peace Activist popularized meditation through Zen Buddhism. This Vietnamese Buddhist Monk wrote more than 100 books for adults and children - more than 70 in English. In 1967 Dr. Martin Luther King Jr. nominated this Peace Activist for a Nobel Peace
Prize. Some years after in Paris, Thich Nhat Hahn established a mindfulness retreat center, Plum Village. He opened monasteries in Hong Kong, Australia, and New York. The organization trains teachers in Europe, Asia, and America through a program called Wake Up Schools [1].

Jack Kornfield, a Buddhist practitioner trained as a Buddhist Monk in Vipassana and co-founded the Insight Meditation Society in Massachusetts. He has taught meditation since 1974. The meditation teacher speaks of the ten perfections in Your Buddha Nature. These ten perfections are (1) generosity (2) morality (3) renunciation (4) insight (5) energy (6) patience (7) truthfulness (8) resolution (9) loving-kindness and (10) equanimity [2].

From where did these qualities originate? Why is it important to allow these human qualities to surface? Is the purpose of the contemplative practice for the individual's peace of mind or is there something else? The Dalai Lama's educates at the International Conference on Buddhism and Literature 2001. "Part of Buddhist practice involves training our minds through meditation. But if our training in calming our minds, developing qualities like love, compassion, generosity, and patience, is to be effective, we must put them into practice in day-to-day life. Being more concerned for the suffering of others instead of your own is truly to follow the spirit of all the great religions including Buddhism [3]."

Jon Kabat-Zinn, Ph.D., a student of Zen Buddhism, first facilitated a stress-reduction program at a Massachusetts hospital in 1979. The effective program became the Mindfulness-Based Stress Reduction Program (MBSR). Participants learn mindfulness meditation, body awareness, and hatha yoga asanas to reduce the distress of psychological and medical conditions. Twenty years of research with adults supports the physical and mental benefits of mindfulness MBSR addresses the body-mind connection [4].

Mindfulness-based programs have expanded to business and organizations transforming habits and behaviors. During the mind training, the practitioner develops the ability to let thoughts come and go without judgment. This skill gives the experience of freedom at that moment. In time, she observes challenging emotions and maintains inner peace. Decision making improves. 
Spiritual communities and programs offer mindfulness classes. The public has access to over 1300 apps for mindfulness meditation - both free and paid. Available, for example, is an app with over 10,000 guided meditations! In addition, school teachers wishing to bring calm to the children and in the classroom have a choice of apps.

\section{Youth and Mental Health}

Since 2007, The American Psychological Association has conducted an annual survey that measures the attitudes and perceptions of stress in the public. Teens were the subject of their 2013 report on mindbody health. Their paper, Stress in America: Are Teens Adopting Adults' Stress Habits? Reveals that the challenges teens reported are more than adults. Youth are uncertain of stress management strategies and assess their stress levels as unhealthy. The majority have the habit of taking the time to manage stress a few times a month. Approximately one-third experienced sadness, feeling overwhelmed or depressed one month prior to the survey. While $40 \%$ reported feelings like irritability and nervousness. Findings suggest that patterns of stress behaviors may begin developing early in our lives (Anderson N, Belar C, Breckler SJ, et al 2014). Is there a case for laying the foundation for inner health in children? [5].

Research studies to understand youths' concerns began in 1958 at the University of Minnesota. A young youth director, Merton Strommen, developed a survey for his doctoral dissertation. The organization published its first book in 1960 - What Youth Are Thinking: Insights from Lutheran Youth Research.

Since that time the name Lutheran Youth Research evolved to Search Institute. This institute develops resources, tools, and practices to support youth. Their findings underscore the value of caring adults in the development of young people. Such adults challenge growth and expand horizons. Subsequent surveys affirm that close connections with friends, siblings, and other peers could achieve this same type of development [6].

This endorses relationships' contribution to personal development and equates the wisdom teachings of Buddhism. Buddhists place high value on spiritual friendships both with teachers and peers. Relationships foster growth as they are both challenging and supportive. "Should you find a wise critic to point out your faults, follow him as you would a guide to hidden treasure." Verse 76 of the Dhammapada.

The youth in the United States have occupied our attention. What of youth in the Scandinavian countries in general and Sweden in particular? How is their mental health? Sweden is a family-friendly country. Two surveys provide insight into the mental health of youth in that country.

The first study reports the decline in the mental health of the children across the board, and that explanation of why this is unclear. In addition, the number of children receiving care from mental health hospitals show an increase. Primary conditions are depressive and anxiety disorders, and drug dependence. The Nordic Center for Welfare and Social Issues produced this 2016 report [7].

Another research study asks the question whether one of the causes of the mental health decline could be the firm beliefs in individuality and self-fulfillment. And whether these cultural beliefs stifle spirituality and spiritual development in children and youth. The author Westerlund wondered whether the term "Spiritual illiterate" could be used to describe Sweden [8].

What beliefs must a young person develop concerning self, others and the world to foster spiritual growth and healthy relationships with both competition and cooperation? Can caregivers build their inner resources to show kindness to those students whose behavior is combative? How important is it that someone in the school community takes responsibility and claim the damaged youth?

Beck and Malley in their discussion of programs that promote the sense of belonging in students state: "The psychological sense that one belongs in a classroom and school community is onside red a necessary antecedent to the successful learning experience. In an era when traditional sources of belonging have diminished due to changing family and community demographics, the school plays an increasingly important role in meeting this need.'[9].

\section{Spirituality and Ubuntu}

Mindfulness programs continue to spread in a secular way providing participants with physical and mental benefits. What of the spiritual side of the human being? Has there been any attention given to spirituality in any sector? Over the last ten years, there has been an interest in spirituality in the fields of health, education, clinical psychology and psychotherapy, and many other disciplines [10]. Key questions posed and answered were, "What is spirituality?", and "What develops in spiritual development?" The 120 international advisers agreed on 10 "principles" for spiritual development globally. One principles is that the "principles" would be considered "an initial working definition" [10]. From the 10 principles, the following three, in my opinion, are relevant to this discussion on cooperative relationships - Ubuntu.

1. The framework should be relevant (though not uniform) across gender, age, and socioeconomic, cultural, racial, and ethnic diversities.

2. Spiritual development involves an inner journey of discovery and awareness, an outer journey of discovery and awareness, and the intersection of the two.

3. Spiritual development has the potential to contribute to the health and well-being of self and others or to harm self and others.

If you know the word Ubuntu as an operating system, you may be aware that it is named after the South African ideology of humanism and interdependence. The operating system, Ubuntu, is distributed as free and open software. Indeed, people refer to someone who is generous as having Ubuntu.

Ubuntu has many translations. The word itself comes from a linguistic group of Sub-Saharan languages known as Bantu. Ntu means personhood, human, being. Ubuntu affirms the interconnectedness of people. This lived philosophy promotes community and kindles a sense of belonging. Imagine this notion that a person can only be healthy by being wholly human in the community. That person is aware of his own contribution to the community. Such a person comes to know his unique and beautiful self by being in community. In addition, he becomes aware of his personal duties and rights. This development of the communal self takes time. It is in the community amongst like-minded persons where you can develop fully and be happy [11]. 
With mindfulness meditation, spiritual qualities develop. The practitioner that follows the philosophy and practices of Buddhism or any religious or spiritual tradition, may enter a compassionate relationship with self and community. She may begin to speak to herself with kindness. And in time the ten natural qualities or perfections listed above unfold. As the physical, mental and spiritual benefits accrue with mindfulness, Ubuntu invites us to develop both that "independent" and our communal self. A supportive community recognizes and appreciates the unique gifts and talents of each member. What would make a person a confident, social, and appreciated member in a community? A person (1) conscious that she is the recipient of gifts and talents, (2) has identified them, and (3) excited to develop and make her meaningful contribution to community.

The more self-fulfilled and grateful the member is the happier. In positive psychology research, gratitude is strongly and consistently associated with greater happiness. This statement originates from Harvard Health Publishing article, Giving Thanks Can Make You Happier. Benevolence grows with cooperation and caring about the needs of community. Generosity blooms with the intention to see what's special in another and the member gives this her best shot. The community provides the communal self opportunities to lead with heart in relationships [12].

\section{Humanness}

As a woman of African Caribbean descent and yoga practitioner, I am curious regarding traditional spirituality across Africa. My search led me to Kemet (now called Egypt) where I discovered the ancient philosophy of Maat. In the book Egyptian Yoga, Dr. Muata Ashby explains "Maat is a way of life that is purifying to the heart and beneficial for society as it promotes virtue and order" [13].

Denise Martin points out, "Maat represents the ethical and moral principle that every Egyptian citizen was expected to follow throughout their daily lives. They were expected to act with honor and truth in manners that involve family, the community, the nation, the environment, and the gods." Denise Martin [14].

In the journey to develop the communal self, reflection is a tool to increase self awareness. Questions like, During the day, when did individualism become a priority over relationships, community and the environment? Did I put "we" before "me"? How did the quality of these interactions impact relationships in that moment and connection in the future?

Western society encourages developing an independent self for successful launch into society, putting I first without restraints from community. The fact is from the beginning of life the baby is dependant. She grows interdependently. Then in the final stages of life, dependency is normalcy. Must independence sacrifice the cooperative spirit, community, and heart? How does the communal self enhance self-fulfillment, prosperity, and the experience of freedom?

Ubuntu promotes a connection that deepens a person's sense of belonging and spiritual growth. Being mindful together with ethical relationships foster a state of well-being and abiding peace. Mindful living and Ubuntu together lay the foundation for inner health from where the person purposefully converges with the outer world and does so with increased wisdom and heart.

\section{References}

1. Thich Nhat Hahn's Vision for Cultivating Mindfulness in Education. https://wakeupschools.org/

2. Teaching on the Ten Perfections by Jack Kornfield - Your Buddha Nature https://jackkornfield.com/books-audio-programs/.

3. Dalai Lama's speech at the $1^{\text {st }}$ International Conference on Buddhism and Literature in 2001.https://www.dalailama.com/ messages/buddhism/buddhism-buddhism-and-literature.

4. Grossman P, Niemann L, Schmidt S, Walach H (2004) Mindfulness-based stress reduction and health benefits A metaanalysis. Journal of Psychosomatic Research 57: 35 -43.

5. Anderson N, Belar C, Breckler SJ (2014) Stress in America: Are Teens Adopting Adults Stress Habits? 2014 https://www. apa.org/news/press/releases/stress/2013/stress-report.pdf :36

6. Sullivan T K, Sethi J, Roehlkepartain EC (2016) the power of peer relationships: A study of peer programs in the United States. Minneapolis, MN: Search Institute.

7. Sommer M (2017) Mental Health among Youth in Sweden. Who is Responsible? What is being done? https://nordicwelfare.org/ wp-content/uploads/2017/10/sverige_webb-1.pdf

8. Westerlund K (2016) Spirituality and mental health among children and youth - a Swedish point of view. International Journal of Children's Spirituality 21: 216-229.

9. Beck M, Malley JA (2003) pedagogy of belonging. EJournal of the International Child and Youth Care Network (CYC-Net) http://www.cyc-net.org/cyc-online/cycol-0303-belonging.html.

10. Benson PL, Scales PC, Syvertsen AK, Roehlkepartain EC (2012). Is youth spiritual development a universal developmental process? An international exploration, The Journal of Positive Psychology 7: 453-470.

11. Battle M Ubuntu (2009) I in You and You in Me. New York: Seabury Books 2009: 2-6

12. https://www.health.harvard.edu/healthbeat/giving-thanks-canmake-you-happier.

13. Ashby M (2005) Egyptian Yoga: The Philosophy of Enlightenment. Cruzian Mystic Books 2005: 661.

14. Martin Denise (2008) Maat and order in African Cosmology: A Conceptual Tool for Understanding Indigenous Knowledge. Journal of Black Studies 38: 951-967.

Copyright: (C2019 Heather Greaves. This is an open-access article distributed under the terms of the Creative Commons Attribution License, which permits unrestricted use, distribution, and reproduction in any medium, provided the original author and source are credited. 